\title{
The Relationships Between the Female Labor Force Participation Rate and Economic Development: A Correlation Analysis for Turkey
}

\author{
Asst. Prof. Dr. Ayfer Ustabaş (Beykent University, Turkey) \\ Assoc. Prof. Dr. Tanses Yasemin Gülsoy (Beykent University, Turkey)
}

\begin{abstract}
Integration of women into the labor market has been a crucial indicator of economic development and social welfare. Although Turkey has taken important steps in terms of integrating with the world economy by shifting from an import-substituting industrialization model to an export-oriented growth strategy from the 1980s onward, female labor force participation rates and the significant regional variations in these rates indicate that women's integration into the labor force has still some ways to go to reach the level of EU and OECD countries. The influence of economic growth on female employment participation has been discussed in many studies. But, studies analyzing the interdependent relationship of female labor force participation and economic growth as well as the interplay of female labor force participation and sectoral GDP growth have been limited. The purpose of this study is to fill this gap by evaluating the relationships between female labor force participation rate and economic growth expressed by GDP per capita levels in Turkey for the 1990-2015 period, using data from the World Development Indicators (WDI) 2017 database of the World Bank. The empirical findings point to a strong correlation between the rate of female labor force participation in industry and services sectors and economic development.
\end{abstract}

\section{Introduction}

Gender equality and women's empowerment are "fundamental" dimensions of human development (United Nations Development Programme, 2016: 165). UNDP underlines the importance of gender equality to sustainable development by formulating its sustainable development goal number 5 to address "... achiev[ing] gender equality and empowering all women and girls" (United Nations Development Programme, 2016: 94). UNDP reports on studies that have found gender equality's positive influence on economic growth, poverty reduction, and human development (ibid., p. 42), but the reverse, as noted in the same report, is not necessarily true. In other words, economic growth does not necessarily lead to gender equality. Consequently, it befalls governments to ensure gender equality (ibid., p. 42).

Women's full integration into the economy is desirable for several reasons. First, as noted by Tansel (2002: 3), the equity perspective leads to the implication that women's increasing labor market participation will improve their relative economic position. Secondly, the efficiency perspective indicates that this participation will also affect positively the overall economic efficiency and improve development potentials of the country (Tansel, 2002: $3)$. Economic empowerment of women will also allow efficient use of government investments in education since working women are generally more involved in making decisions in relation to their children's education and health, creating positive externalities in terms of future generations' welfare (International Bank for Reconstruction and Development and State Planning Organization, 2009).

Women's economic contribution is not limited to the time when they are officially employed. Human Development Report 2016 indicates that women are globally less represented in paid employment than men. In 2015, globally 36 percent of women and 44 percent of men worked in paid employment (Hunt and Sunman, 2016, as cited in United Nations Development Programme, 2016: 42). On the other hand, women's economic contribution in unpaid and especially in domestic work is significant. A 2011 survey conducted in 46 countries indicated that to 28 percent of women who spent three to five hours a day on household work, men's percentage was only 6 (Hunt and Sunman, 2016, as cited in United Nations Development Programme, 2016: 42). As a result, the total time spent by women on paid work as well as unpaid work is higher than for men. Women work on average fifty minutes more a day than men during the course of both paid and unpaid work (World Economic Forum, 2016: 31).

The global labor force participation rate is 49.6 percent among women and 76.2 percent among men (Human Development Report, 2016: 58). Accounting for 1.16 percent of the world economy with a GDP of 856.8 billion US dollars in 2016 (Turkish Statistical Institute,2017), Turkey is represented by only a 30.4 percent in female labor force participation rate in 2016 (World Bank, 2017).

According to Global Gender Gap Report 2016 (examining the gap between men and women in four fundamental categories: Economic Participation and Opportunity, Educational Attainment, Health and Survival and Political Empowerment) published by the World Economic Forum, Turkey ranks as $130^{\text {th }}$ in global index (in 2006, the country was at the $105^{\text {th }}$ rank), $129^{\text {th }}$ in economic participation and opportunity $(33 / 770.44), 109^{\text {th }}$ in educational attainment and $113^{\text {th }}$ in political empowerment among 144 countries. Although she records progress on closing the 
gender gap in estimated earned income and for professional and technical workers, Turkey shows a widening gender gap for wage equality, number of legislators, senior officials, and managers and as well as female members of parliament (World Economic Forum, 2016: 20-21, 346-347; World Economic Forum, 2015: 346-347).

This study investigates the relationships between female labor force participation rate (FLFPR) and economic growth in Turkey during the period 1990-2015. The study begins with the theoretical framework in Section 2 . The evolution of female employment in Turkey is presented in Section 3. The econometrics literature review is given in Section 4. The method is discussed in Section 5, and the econometric evaluation and results are presented in Section 6. Finally, the conclusion is given in Section 7.

\section{Theoretical Framework}

Regarding the relationship of female labor force participation and economic development, several theoretical analyses can be found in the economic literature. Many studies indicate that there can be significant macroeconomic gains when women develop their full integration into labor market potential (Loko \& Diouf, 2009; Dollar \& Gatti, 1999, as cited in Elborgh-Woytek et al., 2013: 4). Increasing female labor force participation rate is estimated to raise GDP, for example, in the United States by 5 percent, in Japan by 9 percent, in the United Arab Emirates by 12 percent, and in Egypt by 34 percent (Aguirre et al., 2012: 9).

Classic modernization theory relates a country's female labor force participation rate to the country's modernization process during the course of which agrarian societies are shifted to industrialized and modernized ones. During this industrialization process, women's social status is expected to be improved as a result of modernization changes like urbanization, decreasing fertility rates, increasing educational and work opportunities and improving working conditions (Inglehart \& Norris, 2003). Alternatively, many of the studies analyzing the modernization effects on women's labor force participation indicate a non-linear relationship: Women's labor force participation decreases in the earlier phases of modernization and then increases in the later phases (Goldin, 1994; Gündüz-Hoşgör \& Smits, 2001; Pampel and Tanaka, 1986).

Goldin (1994) emphasized that labor force participation rate of women first decreases and then rises as countries develop. The downward portion of the $U$ is due to the movement of production from the household to the factory, and to a combination of an initially strong income effect and a weak substitution effect. But, the income effect weakens and the substitution effect strengthens at some point where women's educational resources increase and therefore the ability to obtain jobs in more prestigious occupations rises. These two factors increase the substitution effect and decrease the income effect, and the upward portion of the $U$ is observed and women's labor force participation enters the modern era (Goldin, 1994: 28). Accordingly, cross-country data indicates that high-income and low-income countries have the highest female labor force participation rates while middle-income countries have the lowest (Pampel and Tanaka, 1986; Psacharopoulos and Tzannatos, 1989).Some researchers did not agree on a U-shaped pattern for female labor force participation over the course of economic development and argued that female labor force participation depended on too many variables and thus could not be generalized by the Ushaped hypothesis (Durand, 1975; Standing, 1978).

Another group of researchers explained the U-shaped relationship by pointing to the changes on female labor force participation rate depending on per capita income. When per capita income is at lower levels, female labor force participation rate is at higher levels, indicating the necessity to work in the face of lack of social protection programs. With higher per capita income and increasing social protection, women may withdraw from employment to work at home. Finally, at advanced industrialized income levels, labor force participation becomes higher as a result of a number of factors and processes such as better education, lower fertility rates, and the availability of market-based household services (Duflo, 2012; Tsani et al., 2012).

According to the development perspective, in pre-industrial societies, women's participation in production activities was higher since most production took place at home. On the other hand, in the early industrialization phase, the opportunities for women to be economically active were reduced as a result of the mechanization of farming. Moreover, new jobs that required physical prowess emerged which negatively affected women's labor force participation as those jobs were considered to be incompatible with women's roles at home (Pampel \& Tanaka, 1986; Rau \& Wazienski, 1999; Scott \& Tilly, 1975).

The U-shaped curve hypothesis has been advanced as a good explanation for the low female labor force participation rate in Turkey, which may be in the intermediate phase of modernization (Gündüz-Hoşgör and Smits, 2008: 105). In other words, Turkey may be at the dip of the U-shaped curve where female employment rates are lowest. But, since the country's female labor force participation rate is lower than in other countries at similar levels of development in South-East Asia or Latin America, this difference requires some additional explanations that take into account cultural and economic factors specific to Turkey, as Gündüz-Hoşgör and Smits have noted (2008: 105).

Several cross-country analyses indicated that export promotion and trade liberalization policies might be one of the factors of feminization of the labor force in developing countries (Wood, 1991; Cagatay and Ozler, 1995). Increased globalization and openness to the world economy are expected to generate an increase in female labor 
force especially due to lower unit labor costs of women relative to men. As a result, it is mostly argued that women typically hold low-skill and low-paying jobs, and they tend to be concentrated in export-oriented sectors such as textile, garments and food processing which are more compatible with their traditional roles (Başlevent and Onaran, 2004; Ross, 2006).

\section{Evolution of Female Employment in Turkey}

Turkey has experienced some structural and social changes that would be expected to facilitate Turkish women's labor force participation. In the 1980s, Turkey adopted a market-oriented and liberalized economic model instead of the import-substitution development model implemented in the 1960s and 1970s. Subcontracting and outsourcing practices in the labor market as well as rapid urbanization were other important outcomes of this strategic reorientation (Buğra and Yakut-Çakar, 2010, 521-522). Despite these factors, Turkey represents a rare exception to the worldwide increase in female employment: This rate has declined in the country as a whole, from 34.1 per cent in 1990 to 30.4 per cent in 2016, as Figure 1 indicates. In European Union and OECD member countries, on the other hand, female labor force participation rate has increased within the same period from 45.8 percent to 51 percent and from 47.8 percent to 51 percent, respectively. In the Middle East and North Africa region, this rate has again shown an increase - from 18.3 percent to 21.6 percent (World Bank Indicators, 2017).

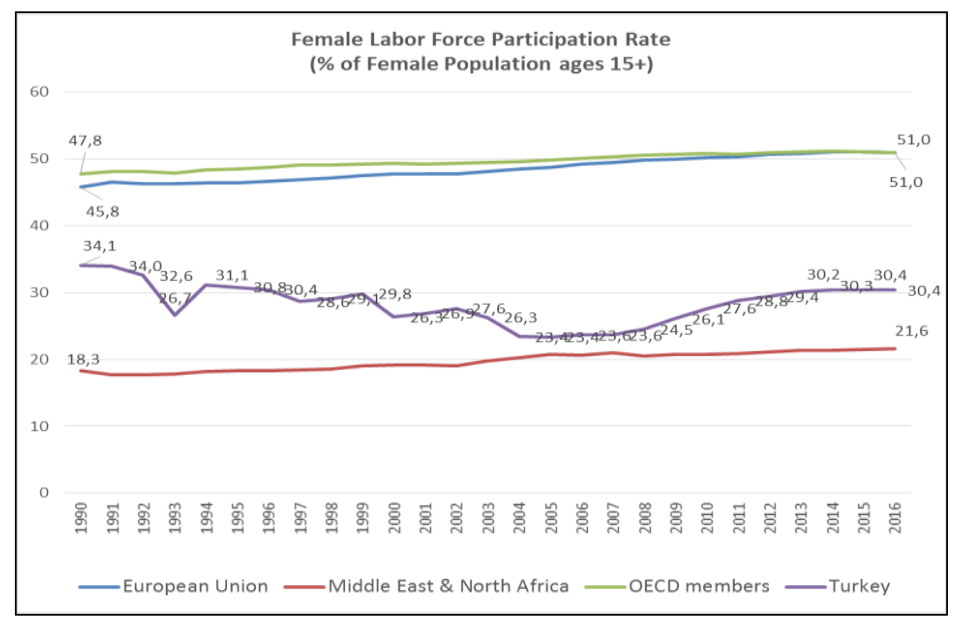

Figure 1. Female Labor Force Participation Rate in Turkey and Some Selected Regions Between 1990 and 2016 Source: World Bank, World Development Indicators 2017.

As a result of international trade liberalization policies, export competitiveness was encouraged and state-run enterprises were privatized. Thus, in Turkey female employment in light manufacturing increased, as had been the case in other export promoting countries (Ross, 2006; Tansel, 2002). The increase of women workers was even more prominent in services such as banking and social and personal services. The percentage of employed females working in the social and personal services doubled between 1985 and 2005, and the percentage working in commercial services quadrupled (Gündüz-Hoşgör and Smits, 2001: 107).

In Turkey, as Figure 2 indicates, the percentage of female labor force in agriculture was 77.4 per cent in 1991, but this ratio declined to 31.1 per cent in 2015. On the other hand, female labor force percentage in industry rose from 8.3 in 1991 to 16.2 in 2015 . Moreover, female employment has shown a spectacular increase in the services sector by rising from 14.4 per cent in 1991 to 52.7 per cent in 2015 .

In European Union and OECD member countries, the percentage of female labor force in services is always higher than the other sectors and this ratio rises from 71.6 percent in 1991 to 83.9 percent in 2015 for the European Union and from 73.7 percent in 1991 to 85 percent in 2015 for OECD member countries. In European Union, the female labor force participation rate in industry declined from 20.8 percent in 1991 to 12.1 percent in 2015 similar as that in agriculture decreased from 7.4 per cent in 1991 to 3.4 per cent in 2015. Finally, in OECD members, the female labor force participation rate in industry declined from 18.6 percent in 1991 to 11.4 percent in 2015, and that in agriculture decreased from 7.6 per cent in 1991 to 3.2 per cent in 2015 (Figure3). 


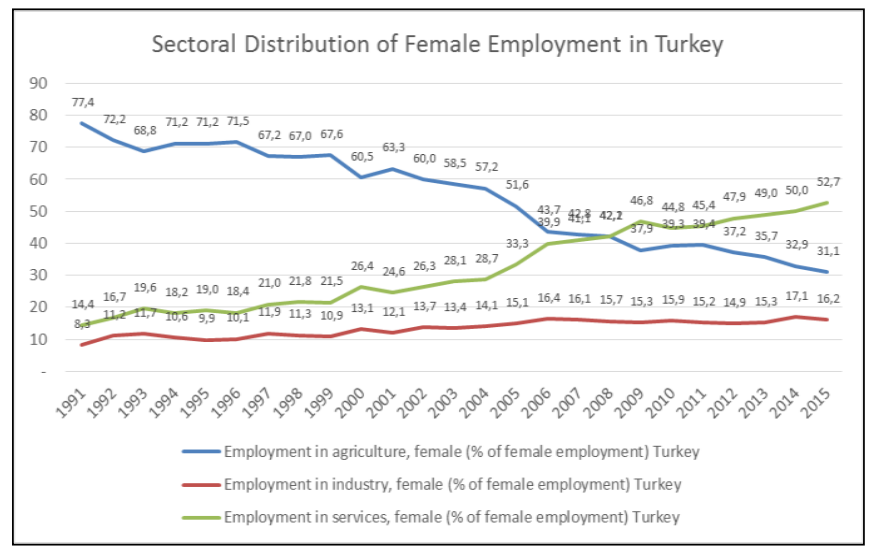

Figure 2. Sectoral Distribution of Female Labor force in Turkey (1991-2015). Source: World Bank, World Development Indicators 2017.

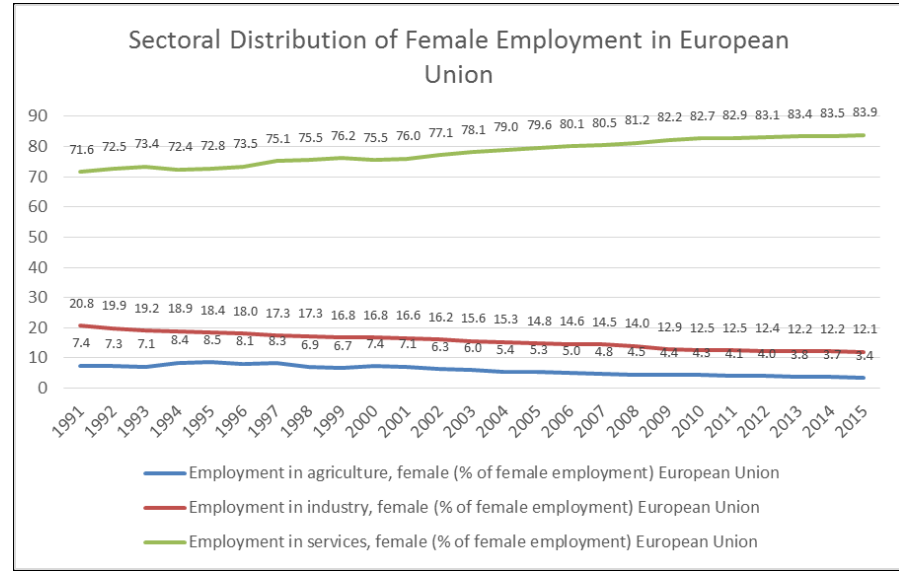

Figure 3. Sectoral Distribution of Female Labor Force in the European Union (1991-2015). Source: World Bank, World Development Indicators 2017.

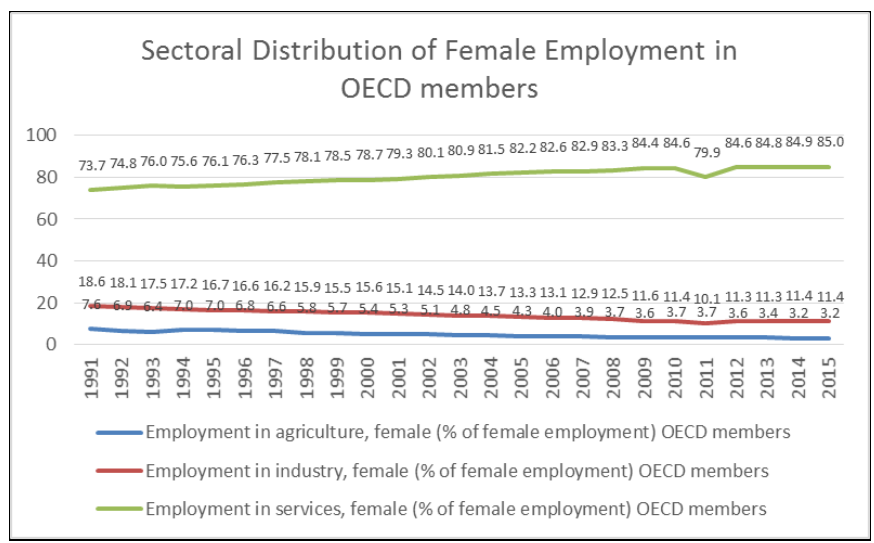

Figure 4. Sectoral Distribution of Female Labor Force in OECD Member Countries (1991-2015). Source: World Bank, World Development Indicators 2017.

In terms of female educational empowerment, adult female literacy rate rose from 68.5 per cent in 1990 to 98.9 percent in 2015 in Turkey (World Bank Indicators, 2017). As it is mostly argued, a more educated female population is likely to have a positive effect on female labor force participation. Furthermore, women are postponing marriage to a later age compared to their female ancestors, which is another factor allowing them to study and participate in the labor force. Despite these favorable indicators, female labor force participation in Turkey appears to be low by international standards (International Bank for Reconstruction and Development and SPO report, 2009: ix).

The reason for the relatively low levels of female labor force participation in Turkey may be a multidimensional issue that must be analyzed from both an economic and a socio-cultural perspective. From the economic perspective, low labor force participation of women is partly explained by the fact that for some women, the market wage level is below their reservation wage, corresponding to the sum of the value of housework and childcare. 
Labor shedding in agriculture is another important factor to be explained in terms of the changing composition of Turkey's female labor force participation. The decline in agricultural production and the concomitant rise in manufacturing and services production have resulted in migration from rural to urban areas, which in turn facilitated the transformation of rural unpaid household women workers into discouraged workers voluntarily withdrawing from the labor market. Another perspective explains the main determinant of insufficient female labor force participation through women's social role of housework and childcare/eldercare responsibilities (International Bank for Reconstruction and Development and SPO report, 2009: 11).

\section{Literature Review and Hypothesis Development}

The relationship between female labor force participation rate and economic development is widely discussed in recent research. Economists performed a variety of statistical tests to prove or disprove the existence of a relationship between the rate of female labor force participation and economic development.

Several researchers hypothesized by using different empirical models that female labor force participation rate exhibits a U-shape during the process of economic development. Goldin (1994) used the data for more than one hundred countries and for the United States and demonstrated that labor force participation of women is generally U-shaped during the course of economic development (Goldin, 1994: 25).

Tansel (2002) explained the U-shaped impact of economic development on female labor force participation rates in Turkey using data for 67 provinces for three time points: 1980, 1985 and 1990. According to the study, after a period of sharp decline (downward portion of $U$ ), the female labor force participation rates have exhibited a decrease in the rate of decline. It is also argued that an upturn in this rate may be expected during the coming decades. The study also indicated that unemployment had an important discouraging effect on female labor force participation while the education impact was strongly positive (Tansel, 2002: 1). Özer and Biçerli (2004) examined the determinants of women's labor force participation rates in Turkey by using panel data regression analyses and did not find a direct influence of macroeconomic variables, such as inflation rate, unemployment rate and growth rate on women's labor participation rates. Moreover, they argued that their finding may indicate a lack of integration of women workers into labor markets due to their traditional roles and therefore these implications have not only economic, but also sociological dimensions (Özer and Biçerli, 2004: 55).

Özler investigated the relationship between export orientation and female share of employment in the Turkish manufacturing sector during 1983-85 using plant-level data and found that an increase in the export share of output at the sectoral level led to an increase in female share of employment at the plant level (Özler, 2000: 1239).

Başlevent and Onaran analyzed the impact of export-oriented growth strategy on female labor force participation and employment in urban Turkey. They found that while the long-term economic growth at the province level was found to have a significant positive effect on both the employment and participation of women, the impact of export-orientation was not as strong in the case of non-married women (Başlevent and Onaran, 2004: 1375).

Recent studies demonstrated that when women can develop their labor market potential fully, macroeconomic gains of an economy increases significantly. Aguirre and others (2012) estimated that GDP of several countries could be increased (in United States by 5 percent, in Japan by 9 percent, in the United Arab Emirates by 12 percent, and in Egypt by 34 percent) by raising the female labor force participation rate to each of these countries' male labor force participation levels. In Japan, the annual potential growth rate could rise by about $1 / 4$ percentage point if female labor force participation rate were to reach the average for the $\mathrm{G} 7$ countries, resulting in a permanent rise of 4 percent in per capita GDP (IMF 2012c, as cited in Elborgh-Woytek et al., 2013).

Higher female labor force participation means greater availability of jobs and also higher level of household income resulting in an increase in consumption and therefore in aggregate income of a country. Therefore, we expect a positive correlation between female labor force participation and per capita GDP.

Hence, our first hypothesis is the following:

Hypothesis 1: There is a positive relationship between female labor force participation rate and economic growth as measured by GDP per capita.

Sectoral distribution of female labor force in Turkey has shown that Turkish female labor force has shifted from agriculture to industry and particularly to the services sector. In the composition of Turkey's GDP in terms of value added, the share of agriculture has decreased from 55.9 in 1960 per cent to 18 per cent in 1990 and to 8.5 per cent in 2015. Industry's value added share has increased to 26.5 per cent in 1960 to 32.1 in 1990 but decreased to 26.5 in 2015. Finally, services value added that was 26.4 per cent in 1960, has shifted from 49.7 in 1990 to 64.5 per cent in 2015. Since the total female labor force includes the female employment in agriculture, it would also be appropriate to analyze separately the correlation between the female labor force in industry and GDP growth and the correlation between female labor force in services and GDP growth (Figure 2) because these two female employment groups are likely to exhibit the same pattern with the economic growth in Turkey where the composition of GDP has been shifted from an agrarian structure to an economy highly dominated by industry and services. 
Based on the above, we also have formulated the following hypotheses:

Hypothesis 2: There is an inverse relationship between female labor force participation rate in agriculture and economic growth as measured by GDP per capita.

Hypothesis 3: There is a positive relationship between female labor force participation rate in manufacture and economic growth as measured by GDP per capita.

Hypothesis 4: There is a positive relationship between female labor force participation rate in services and economic growth as measured by GDP per capita.

The following section delineates the method used for this analysis.

\section{Method}

We have used the World Development Indicators 2017 database of the World Bank for our analyses. We have conducted correlation analyses between two indicators: Turkey's GDP level per capita and female labor force participation rate in the aggregate as well as at the sectoral levels for agriculture, industry, and services. In the study, GDP per capita in constant 2010 US dollars and female labor force participation rate (\% of female population ages $15+=$ Labor Force (Unemployed+Employed) / WAP (Working-age Population aged 15+) (modeled ILO estimate) are taken from the World Development Indicators (WDI) 2017 database of the World Bank. The dataset for GDP per capita and female labor force participation rates (total, agriculture, industry and services sectors) corresponds to the time period 1990-2015. We used the natural logarithms of both variables in the correlation analyses. The data was analyzed using SPSS software.

\section{Findings}

The correlation analysis we have performed to test our hypothesis that the higher the female labor force participation rate, the higher is economic growth as measured by GDP per capita did not turn out to be significant, and the hypothesized relationship was in the opposite direction. Thus, Hypothesis 1 was not supported. As Figure 5 indicates, time series of the female labor force participation rate and the GDP per capita do not show a linear relationship. Moreover, Spearman's rho Correlation coefficient (-0.394) shows that there is a negative correlation between female labor force participation rate and GDP per capita (Tables 1 and 2).

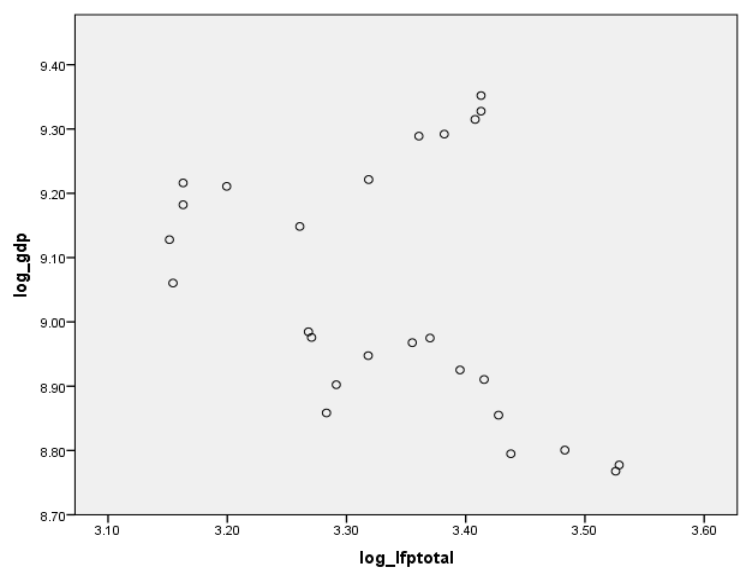

Figure 5. Scatterplot Showing the Series of GDP Per Capita and Labor Force Participation Rate. Source: World Bank, 2017.

In our subsequent analyses we examined the relationship between GDP per capita and the sectoral female labor force participation rate, i.e. FLFPR in agriculture, industry and services.

As it can be seen from the scatter plots presented in Figures 6, 7 and 8, GDP per capita is negatively correlated with FLFPR in agriculture and is positively correlated with FLFPR in industry and FLFPR in services. Accordingly, for the correlation between the GDP per capita and FLFPR in agriculture, the Pearson and Spearman's rho correlation coefficients are respectively $(-0.970)$ and $(-0.967)$ with $(\rho=0.000)$ significance value. As a result, our second hypothesis is supported (Tables 1 and 2).

For female labor force participation rate in industry, the Pearson and Spearman's rho correlation coefficients are (0.905) and (0.912), respectively, both significant at the 0.01 level $(\rho=0.000)$. Similarly, for the correlation between the GDP per capita and FLFPR in services, the Pearson and Spearman's rho correlation coefficients are $(0.974)$ and (0.973), respectively, again both significant at the 0.01 level $(\rho=0.000)$. It can be thus concluded that the correlation between FLFPR in industry and the GDP per capita as well as the correlation between FLFPR in 
services and the GDP per capita are statistically significant. As a result, our third and fourth hypotheses are also supported (Tables 1 and 2).

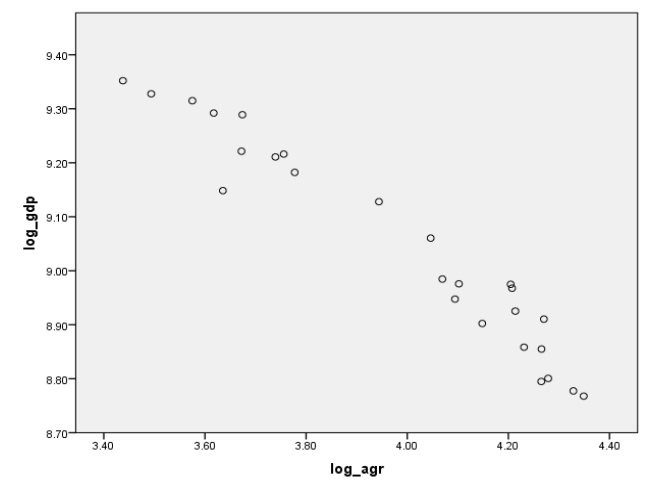

Figure 6. Scatterplot Showing the Series of GDP Per Capita and Labor Force Participation Rate in Agriculture. Source: World Bank, 2017.

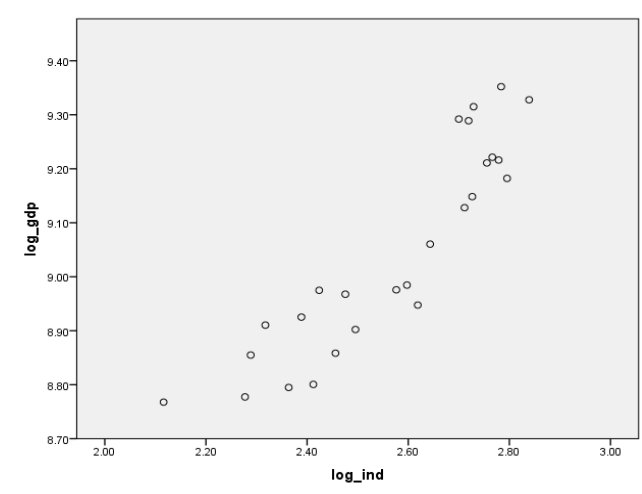

Figure 7. Scatterplot Showing the Series of GDP Per Capita and Labor Force Participation Rate in Industry. Source: World Bank, 2017.

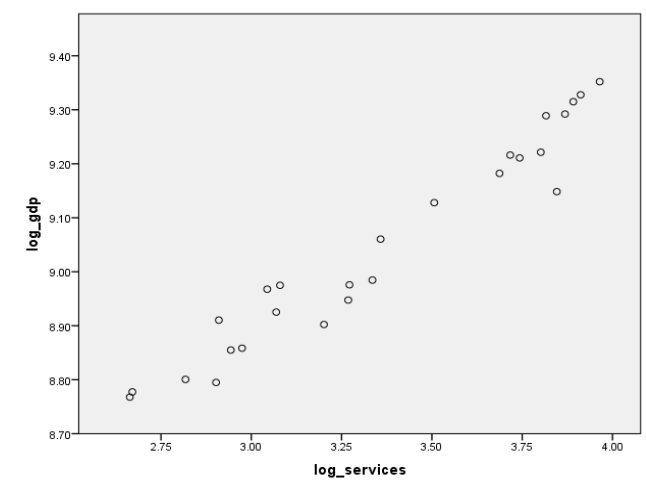

Figure 8. Scatterplot Showing the Series of GDP Per Capita and Labor Force Participation Rate in Services. Source: World Bank, 2017. 


\begin{tabular}{|c|c|c|c|c|c|c|}
\hline & & log_gdp & $\log$ agr & log_ind & log_services & log_lfptotal \\
\hline \multirow{4}{*}{ log_gdp } & Pearson Correlation & 1 & $-.970^{* *}$ & $.905^{* *}$ & $.974^{* * *}$ & -.377 \\
\hline & Sig. (2-tailed) & & .000 & .000 & .000 & .058 \\
\hline & $\mathrm{N}$ & 26 & 26 & 26 & 26 & 26 \\
\hline & Pearson Correlation & $-.970^{* *}$ & 1 & $-.899^{* *}$ & $-.979^{* *}$ & .303 \\
\hline \multirow[t]{3}{*}{ log_agr } & Sig. (2-tailed) & .000 & & .000 & .000 & .132 \\
\hline & $\mathrm{N}$ & 26 & 26 & 26 & 26 & 26 \\
\hline & Pearson Correlation & $.905^{* *}$ & $-.899^{* *}$ & 1 & $.945^{* *}$ & $-.616^{* *}$ \\
\hline \multirow[t]{3}{*}{ log_ind } & Sig. (2-tailed) & .000 & .000 & & .000 & .001 \\
\hline & $\mathrm{N}$ & 26 & 26 & 26 & 26 & 26 \\
\hline & Pearson Correlation & $.974^{* *}$ & $-.979^{* *}$ & $.945^{* *}$ & 1 & $-.456^{*}$ \\
\hline \multirow[t]{3}{*}{ log_services } & Sig. (2-tailed) & .000 & .000 & .000 & & .019 \\
\hline & $\mathrm{N}$ & 26 & 26 & 26 & 26 & 26 \\
\hline & Pearson Correlation & -.377 & .303 & $-.616^{* *}$ & $-.456^{*}$ & 1 \\
\hline \multirow[t]{2}{*}{ log_lfptotal } & Sig. (2-tailed) & .058 & .132 & .001 & .019 & \\
\hline & $\mathrm{N}$ & 26 & 26 & 26 & 26 & 26 \\
\hline
\end{tabular}

**. Correlation is significant at the 0.01 level (2-tailed)

*. Correlation is significant at the 0.05 level (2-tailed).

Table1 - Correlations

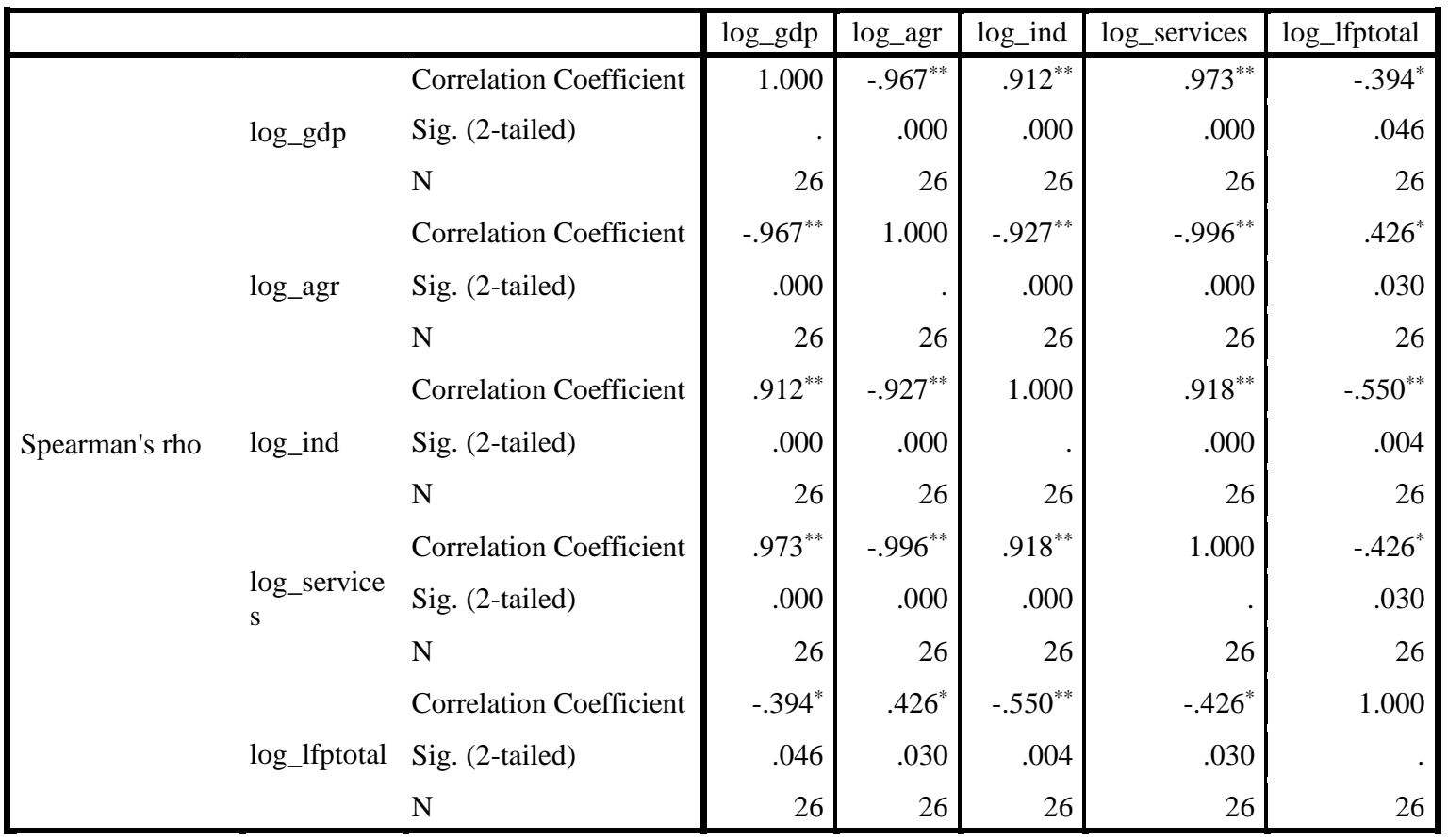

**. Correlation is significant at the 0.01 level (2-tailed).

*. Correlation is significant at the 0.05 level (2-tailed).

Table 2- Correlations

\section{Conclusion, Limitations and Implications for Further Research}

Even though women represent nearly one half of the global population, their contribution to economic activity and growth is still far below its potential. Our tentative results indicate that there may in fact exist a strong positive relationship between women's labor force participation rate in industry and in services and economic growth as measured by GDP per capita. Removing the barriers to women's labor force participation implies greater economic growth. Despite significant progress in recent years, female labor force participation in Turkey remains relatively low by international standards (International Bank for Reconstruction and Development and SPO report, 2009: ix), women account for most of the unpaid work (World Economic Forum, The Global Gender Gap Report 2016: 32 ), and when women are employed in paid work, they also face significant wage disparities compared to male workers (United Nations Development Programme, 2016). 
Increasing the labor force participation of women appears to be contingent upon women's economic empowerment. Non-paid and dangerous work, low pay, lack of social protection and job insecurity are some of the contextual factors that need to be ameliorated. Globally, relatively low wages as compared to men are a general problem of working women. On the other hand, since demographic, economic and cultural factors also contribute to these unfavorable conditions, each country's women labor force differs from others. As a result, in each country and especially in developing and underdeveloped countries, governments are required to apply tailored approaches and solutions to gender issues.

In Turkey, traditional roles of women as child/elder care providers and home makers are important determinants of labor market choice. The influences of a patriarchal society play also an important role in determining women's labor market presence. As such, female employment needs to be analyzed from both economic and socio-cultural perspectives. To increase the female labor force participation in Turkey, first these socio-cultural and economic barriers against women's employment should be recognized and then solutions should be sought to remove these barriers so that women will be encouraged to enter the workforce.

Economic barriers include generally factors such as working in the informal sector as a result of insufficient job opportunities in formal sectors, lower wages compared to male workers, long hours and poor working conditions, and shortage of childcare/eldercare services. Apart from economic barriers, sociological factors related to the traditional role of women as caregiver in the household as well as the lower level of gender diversity in workplaces worsen the effects of economic barriers and weaken women's motivation to participate in the labor force. Despite significant progress in advanced market economies, evidence of gender-based discrimination such as the glass ceiling effect persists there also. Considering the prevalence of these issues confronted by women in the labor market, leadership by international bodies such as the UN as well as national governments appears to be necessary. In fact, leadership by multinational companies as well as big business groups especially in developing economies may also go a long way towards increasing the participation of women in the labor force through implementation of women-friendly corporate policies.

Various policies for increasing the demand for female labor and improving female labor force participation can be suggested: These include government subsidies to increase the hiring of women, decreasing the percentage of informality, and rewarding of public or private enterprises within the scope of best practices.

This study has several limitations. First, it is limited to one country, Turkey, and thus its results may not be generalized to other countries. Secondly, because the data on female labor force participation is limited, the sample size of this study (1990 to 2015) is relatively small. Finally, causal analyses that treat GDP per capita as a dependent variable and female labor force participation among a host of independent variables may enrich our understanding of the interplay between economic growth and female labor force participation. Further research studies that include multiple countries and a wider time range may reveal greater insight into the relationship between female labor force participation and GDP per capita.

\section{References}

- $\quad$ Aguirre, D., Leila Hoteit, Christine Rupp, and Karim Sabbagh, 2012, "Empowering the Third Billion. Women and the World of Work in 2012," Booz and Company.

- Başlevent, C. and Onaran, Ö., 2004, "The Effect of Export-Oriented Growth on Female Labor Market Outcomes in Turkey", World Development Vol. 32, No. 8.

- Buğra, A. and Yakut-Çakar B., 2010, "Structural Change, the Social Policy Environment and Female Employment in Turkey", Development and Change 41(3), International Institute of Social Studies.

- Çağatay, N., and Özler, Ş., 1995, "Feminization of the labor force: the effects of long-term development and structural adjustment", World Development, 23.

- Dollar, D., and R. Gatti, 1999, “Gender Inequality, Income, and Growth. Are Good Times Good for Women?” World Bank Gender and Development Working Paper No. 1.

- Duflo, E., 2012, “Women Empowerment and Economic Development,” Journal of Economic Literature, Vol. 50 , No. 4.

- Durand, John D., 1975, The labor force in economic development. Princeton University Press.

- $\quad$ Elborgh-Woytek, K.; Newiak, M.; Kochhar, K.; Fabrizio, S.; Kpodar, Kangni; Wingender, P.; Clements, B.; \& Schwartz, G. 2013. Women, work, and the global economy: Macroeconomic gains from gender equity. IMF Discussion note. International Monetary Fund (Strategy, Policy, and Review Department and Fiscal Affairs Department).

- Goldin, C. 1994, "The U-Shaped Female Labor Force Function in Economic Development and Economic History" National Bureau Working Paper No. 4707.

- Gündüz-Hoşgör, A. and Smits. J., 2008, "Variation in labor market participation of married women in Turkey”, Women's Studies International Forum 31. 
- Inglehart, R., \& Norris, P., 2003, Rising tide: Gender equality and cultural change around the world. Cambridge Cambridge University Press.

- International Bank for Reconstruction and Development (World Bank) and SPO (State Planning Organization) Report, 2009, "Female Labor Force Participation in Turkey: Trends, Determinants and Policy Framework", Report No: 48508-TR.

- Loko, B., and Mame A. D., 2009 “Revisiting the Determinants of Productivity Growth: What's New?" IMF Working Paper 09/225 (Washington).

- Özer, M. and Biçerli, K. “Türkiye’de Kadın İşgücünün Panel Veri Analizi”, Sosyal Bilimler Dergisi 20032004.

- Özler, Ş. 2000, "Export Orientation and Female Share of Employment: Evidence from Turkey", World Development Vol. 28, No. 7, 2000.

- Pampel, Fred C., \& Tanaka, K., Economic development and female labor force participation: A reconsideration. Social Forces, 64.

- Psacharopoulos, G. and Z. T., 1989, Female Labor Force Participation: An International Perspective. World Bank Research Observer, 4(2).

- $\quad$ Rau, W., \& Wazienski, R., 1999, Industrialization, female labor force participation, and the modern dividion of labor by sex. Industrial Relations.

- $\quad$ Ross, Michael, 2006, Does oil hurt the status of women? Los Angeles UCLA Department of Political Science Working paper.

- Scott, Joan W., \& Tilly, L. 1975, Women's work and family in nineteenth-century Europe. Comparative Study of Society and History, 17, 36-64.

- Standing, G., 1978, Labor Force Participation and Development, Geneva: International Labor Office.

- Tansel, A. 2001, "Economic Development and Female Labor Force Participation in Turkey: Time-Series Evidence and Cross-Province Estimates", Middle East University.

- Tsani, S., Leonidas P., Costas F., Ioannis C. and Pantelis C., 2012, "Female Labor Force Participation and Economic Development in Southern Mediterranean Countries: What Scenarios for 2030?" MEDPRO Technical Report No. 19, European Commission.

- Turkish Statistical Institute, March Report No: 24566, http://www.tuik.gov.tr/HbGetirHTML.do?id=24566.

- UNDP, Human Development Report, 2016.

- Wood, A. 1991, North-South trade and female labor in manufacturing: an asymmetry. Journal of Development Studies, 27.

- World Bank, World Development Indicators, WDI Database, 2017.http://databank.worldbank.org/data/reports.aspx?source=world-development-indicators\#

- World Bank, http://data.worldbank.org/indicator/NV.SRV.TETC.ZS?locations=TR.

- World Economic Forum, (2015) The Global Gender Gap Report 2015. Geneva, Switzerland: World Economic Forum.

- World Economic Forum, (2016) The Global Gender Gap Report 2016. Geneva, Switzerland: World Economic Forum. 